\title{
Industry 4.0 Performances of OECD Countries: A Data Envelope Analysis
}

\author{
Mert YILDIRIM (iD) a Mehmet Selami YILDIZ iD b İsmail DURAK iD c \\ a Düzce University, Institute of Social Sciences, Düzce, Turkey. yildirimmert2427@gmail.com \\ b Düzce University, Faculty of Business Management, , Düzce, Turkey. selamiyildiz@duzce.edu.tr \\ c Düzce University, Department of Quantitative Methods, School of Business, Düzce, Turkey. ismaildurak@duzce.edu.tr
}

\begin{tabular}{|c|c|}
\hline ARTICLE INFO & ABSTRACT \\
\hline Industry 4.0 Performance & $\begin{array}{l}\text { Purpose - The aim of the study is to make a comparative analysis of Industry } 4.0 \text { performances of } \\
\text { OECD countries. }\end{array}$ \\
\hline $\begin{array}{l}\text { Data Envelope Analysis } \\
\text { OECD }\end{array}$ & $\begin{array}{l}\text { Design/methodology/approach - In this study, Data Envelopment Analysis, Bootstrap Data } \\
\text { Envelopment Analysis and Malmquist Total Factor Efficiency Index methods were used for 2013, } \\
2014,2015 \text { by using Industry } 4.0 \text { indicators of } 25 \text { OECD countries whose data were available. }\end{array}$ \\
\hline $\begin{array}{l}\text { Received } 7 \text { July } 2020 \\
\text { Revised } 7 \text { September } 2020 \\
\text { Accepted } 15 \text { September } 2020\end{array}$ & $\begin{array}{l}\text { Findings - As a result of the study, while Austria, Belgium, Czech Republic, Denmark, France, } \\
\text { Germany, Japan, S. Korea and Sweden were generally effective and there was no overall } \\
\text { improvement in the country's efficiency scores over time, some countries such as Canada, Latvia, } \\
\text { Slovakia, Estonia and Sweden, had increased their effectiveness in time. }\end{array}$ \\
\hline $\begin{array}{l}\text { Article Classification: } \\
\text { Research Article }\end{array}$ & $\begin{array}{l}\text { Discussion - Considering the studies in which the comparative analysis of Industry } 4.0 \\
\text { performances in the countries was analyzed, it was reached that the variables used in the studies } \\
\text { and the results obtained from the analysis were similar. In this respect, the findings of the study } \\
\text { were consistent to the literature. }\end{array}$ \\
\hline
\end{tabular}

\section{Introduction}

Industry 4.0 is one of the most popular concepts studying in the literature in recent years. Industry 4.0 has also been an important agenda topic at the Davos Summit held by the World Economic Forum in 2016. With globalization, it has become inevitable to adapt the increasing competition and respond to rapidly changing consumer demands and desires on time. This makes it necessary to reevaluate perhaps all processes of production activities. These revolutions are aimed to reduce the need for labor factor especially in production processes and convert production processes to autonomous. It is also expected to increase competitiveness, decrease the costs, use resources effectively and, reduce human-induced errors in the production and operations process. For all these reasons, the integration of countries into Industry 4.0, which is a digital transformation, is notably important. The aim of this study is to make a comparative analysis of Industry 4.0 performances of OECD countries.

In the first part of the study, after making an introduction to the study, the importance, aim and plan of the study were given. In the second part of the study, information about Industry 4.0 and its components (Internet of things, smart factories, artificial intelligence, 3D printers, big data, autonomous robots, and cyber security) were elaborated. In the third part of the study, Data Envelopment Analysis, Bootstrap Data Envelopment Analysis and Malmquist Total Factor Efficiency, which are among the quantitative research methods performed with the help of indicators for measuring Industry 4.0 were explained. In the fourth part of the study, domestic and foreign literature review related to Industry 4.0 was given. In the fifth part of the study, the findings of Data Envelopment Analysis, Bootstrap Data Envelopment Analysis and Malmquist Total Factor Efficiency Analysis to determine the relative performance of OECD countries in terms of Industry 4.0 were presented. In the last part of the study, the conclusion of the study was given, which includes the results of the study and comparisons with the results of similar studies in the literature, as well as suggestions for future researchers.

\section{$\underline{\text { Suggested Citation }}$}

Yıldırım, M., Yıldız, M., S., Durak, İ. (2020). Industry 4.0 Performances of Oecd Countries: A Data Envelope Analysis, Journal of Business Research-Turk, 12 (3), 2788-2798. 


\section{Industry 4.0 and Its Components}

Industry 4.0 is a concept that forms a unity with autonomous robots, artificial intelligence, internet of things, big data, cyber security, additive manufacturing (3D printers) and smart factories (Hermann et al., 2015: 11). In Industry 4.0, products within the production area search for the shortest route to the production machine. The machines are automatically informed and order spare parts automatically. If an error occurs in the machine, the machine automatically changes the production plan (Kaufmann, 2015: 32-38). The new level of technology, with Industry 4.0 can be called the fourth level of industrialization.

\subsection{Internet of Things}

The first Internet of Things application in history is the sharing of images of a coffee machine with a camera system by a group of scientists working at Cambridge University in 1991 (Armentia et al., 2012). It is explained that the concept of Internet of Things is also called "Industrial Internet" and this expression is a new technology paradigm designed as a machine and device network that can interact with each other (Lee and Lee, 2015: 431). In other words, the internet of things is defined as the network of physical objects such as tools, machines, and household appliances (Thibaud et al., 2018: 79). It refers to the technological development that allows objects and machines such as the Internet of Things, mobile phones and sensors to "communicate" with each other to produce solutions with people. The integration of this technology allows objects to solve problems independently (Brettel et al., 2014: 37-44).

\subsection{Smart Factories}

Smart factories are generally considered to be a very important feature of Industry 4.0. The discovery of other components that make up Industry 4.0 in production in a factory environment is called a smart factory. The operation of a smart factory is driven by customer requests and the internet of things is used to meet demand. The basic philosophy is to use data from the physical and non-real world to provide assistance for people and machines to perform their duties (Obitko and Jirkovsky, 2015: 220). Industry 4.0 is expected to integrate multiple factories or geographical areas, breaking the boundaries between factories. This new technology designs a system that integrates data to acquire, transmit, analyze, interpret analysis results, and control the production process as targeted. With the introduction of this technology for production, the term Smart Factory emerged. There are different definitions related to this term in the literature. The smart factory is based on the principle of using the latest technological developments in the field of computer networks, data integration and analytics together. The smart factory defines a multicultural production approach using the latest industrial internet technologies, consisting of smart sensors, and sensing, data processing and analytical analysis and flexible control technologies (Lee, 2015: 4-5). Smart factories, the most prominent feature of which is to enable autonomous control of information, transparency in information and sustainable production, are structures that contain materials, warehouses and machines that are in constant communication with each other and other systems. The quality of the products, which are the subject of production in smart factories, is also smart and determines the most suitable working style with the help of the data that are available and the consumer usage. In this respect, smart factories offer the opportunity to control and monitor production and service regardless of time and place conditions (Radziwon et al., 2014: 1185).

\subsection{Artificial Intelligence}

The concept of artificial intelligence in today's World is based on around five mains aspects: strength, interpretation ability, education, ability, and autonomy. Strength is how smart artificial intelligence is; interpretation ability is whether artificial intelligence can solve the problem defined; education is the learning method of artificial intelligence; capacity is what kind of problems that artificial intelligence can help and autonomy indicates that whether artificial intelligence is only a support or whether it has the ability to move on its own (Lorica and Loukides, 2016: 1). In the industrial sense, artificial intelligence relates, for example, to how the current condition can be increased with machine intelligence in an industry activity branch, or how the combination of machine sensors, people and objects can be realized. All the equipment in the Fourth Industrial Revolution is combined with smart systems based on artificial intelligence (Skilton and Hovsepian, 2017: 270). 


\subsubsection{Printers (Additive Manufacturing)}

3D Printers also known as additive manufacturing is a technology that causes the internet of objects to produce in industrial use. 3D printers print an image that has been designed on a computer as a 3D object. 3D printers that can produce industrial objects used in the car, aircraft and even the healthcare industry offer a faster and cheaper model (Gilchrist, 2016: 60-61). Increasing elasticity and diverse goods production at production facilities has enormous costs. In addition, the development of R\&D and innovation is elements of high costs. However, the costs of 3D printers have been decreasing in recent years and their processing capacities have been increasing gradually (Stock and Seliger, 2016: 539). In the near future, 3D printers; in particular, production-to-order strategies expect to deeply affect the relationship between the manufacturer-wholesalerretailer and change their trading experience. In some sectors, retailers will either not exist because they need to keep their stocks or become showcases. Orders will be fulfilled directly by the manufacturer and will be delivered to the consumer's home (Manners-Bell and Lyon, 2012: 1).

\subsection{Big Data}

Big data is a descriptive concept traditionally used to describe large amounts of data sets that cannot be analyzed and managed with data processing tools (Ohlhorst, 2012: 19). The devices used today are more convenient for data processing. Thanks to the sensors placed on the devices, the data on this device can be received simultaneously and actions related to the device can be obtained accordingly (Schwab, 2016: 52). The term big data was first used by a computer specialist who employed in Silicon Graphics in the 1990s (Howson, 2014: 3). Thanks to the big data analysis approach, data-oriented risk assessment studies for industrial production systems can be presented based on a holistic framework and real-time data. This is of great importance in terms of production optimization (Zheng et al., 2018: 137). Companies can access customer data through mobile applications, social media platforms and search engines. Aside from obtaining big data, it should be analyzed and guided by companies in the decision-making process. Rapid access to data and therefore rapid decision making are crucial for companies to gain competitive advantage. Rapid inclusion of big data in the process necessitates the use of different tools from traditional methods due to the size and complex nature of the data (Kocsi and Olah, 2017: 389). There is a serious problem of information pollution in today's world. This situation increases the importance of accessing correct information day by day. Along with the big data, it is aimed to extract the desired information from the said information pollution.

\subsection{Autonomous Robots}

Robots started to become smart and autonomous with the development of artificial intelligence science. Thanks to the embedded IT hardware and software that robots hold, they can exhibit artificial intelligence applications and establish relations with the outside world. The first autonomous robots that can make decisions and act on their own without any operator intervention were developed by William Gray Walter at the Burden Neurological Institute in Bristol, England, in 1948-1949. Walter's first autonomous robots, called "Elmer and Elsie", were named as tortoises in technology circles due to their shape and slow movement. Threewheeled turtle robots react to the light and thus go to the charging stations due to charging themselves when the battery power was inadequate. When his contemporaries turned to quantitative computing, Walter emphasized the importance of using analog electronics with these robots. The first autonomous robot that functions quantitatively and is called "Unimate" was developed in 1954 by George Devol. This development is considered to be the foundation of the autonomous robot industry. Autonomous robots are now being used to do things more cost-effectively, more accurately and more reliably than humans. In addition, these robots started to work in unhealthy, dangerous, or repetitive jobs that are not suitable for humans (Banger, 2017: 7172). With the use of smart robots, industries can avoid subjective errors and minimize costs by getting rid of human-induced problems (Görçün, 2016: 187). Advances in sensors give robots the ability to better understand their environment, react and take part in a wide variety of tasks such as housework. Unlike in the past, when programming by a special unit was required, robots can now access information remotely via the cloud and thus connect to networks of other robots. Structures that can interact with themselves and people and make autonomous decisions by self-management are defined as smart robots. In addition to industrial activities, robots can rationalize their supply chains to achieve more efficient and predictable business results (Schwab, 2016: 25). 


\subsection{Cyber Security}

The International Telecommunications Authority (ITU) defines the concept of cyber security as a security community of tools and policies (Solms and Niekerk, 2013: 97). Although the concepts of "information security" and "cyber security" are used in many similar meanings in studies, cyber security means ensuring the security of many assets (information, hardware, software, company, building, institution, state or even people) beyond the protection of classical information sources (Solms and Niekerk, 2013: 99). The concept of cyber security was first used by scientists in connection with network and vulnerabilities in computer systems, and later this issue became the subject of other scientific channels with the rapid increase in this threat dimension and its destructive effects (Nissenbaum, 2005: 70).Interface is created with internet communication to create smart factories and production organizations that contain industrial systems. However, existing internet technologies are struggling with cyber security and data privacy issues. There are major challenges and obstacles for those adopting Industry 4.0 technologies. Industry 4.0 brought along its own unique security and privacy issues, along with traditional cyber security issues. Unless these challenges are overcome, the true potential of Industry 4.0 is never expected to be achieved (Thames and Schaefer, 2017: 5).

\section{Literature Review}

While there are limited number of researches that studied on Industry 4.0, several studies have been done recently on it. Öztürk and Alaşahan (2019) compared Industry 4.0 across countries with the Panel data analysis method for a sample of nine countries including Turkey in the Global Innovation Index. In the study, variables such as GDP, Global Innovation Index, High Technology Product Issuance, Number of Patent Applications and R\&D Expenditures were used. According to the results of the study, it was pointed out that Turkey needs to export more technology and perform high-tech production to be a power in Industry 4.0. Furthermore, the findings suggest that Turkey should give more importance to education and R \& D studies in this area. There is a number of studies that empirically compared Turkey with several countries as Germany, Japan, Finland under Industry 4.0 and Innovation Indicators over several variables (Bulut and Akçac1, 2017). These variables were the ratio of $R \& D$ expenditures to gross domestic product, technology ratio within the expenditures of private and public sectors, the ratio of engineering and technology within the R\&D expenditures in higher education, the share of internet use in the total population, the ratio of advanced technology exports to total exports, As a result of the research, it was concluded that increasing R \& D expenditures for Turkey has an increasing effect on technology exports. Likewise, another study examined comparatively firms in Turkey and European Union countries in empirical analysis on the transition to Industry 4.0 (Ünlü and Atik, 2018). In the study, ten different criteria were selected from the report titled Monitoring the Digital Economy \& Society 2016-2021 published by the European Commission as criteria for businesses. The criteria were that share of companies using portable devices for mobile connection to the Internet, share of companies that take orders over the internet, share of companies using software such as customer relationship management (CRM), companies with enterprise resource planning (ERP) software package to share information between different functional areas, share of companies using broadband access, companies using paid cloud computing applications, companies using internet in communication with public institutions, share of companies using corporate resource planning (ERP), share of companies using customer relationship management (CRM), share of information in the supply chain. The study's results were evaluated by using factor analysis and cluster analysis. As a result of the study, Germany was ranked first, while the Turkey ranked as 15th. Moreover, another study was examined the level of Industry 4.0 in the defense industry by the hesitant AHP method Ataman (2018). Using five main criteria with three experts in their field, questionnaire method was applied on strategy, management and organization, human and R\&D culture, product and technology, operation and seventeen sub criteria. As a result of the study, it was revealed that the strategy criterion was more important than the others with the evaluation of the experts.

On the other hand, Wang and Liu (2014) pointed out the effects of Industry 4.0 on reducing costs, and in this context, they drew attention to the use of the internet of things concept in the agricultural sector. It was concluded that the application of the Internet of things in the agricultural supply chain helps to improve the level of agricultural supply chain information technology, thereby improving the operational efficiency of the supply chain of agricultural products by improving the whole supply chain integration. Schumacher et al (2016) conducted a survey of 62 questions on Industry 4.0 in their study. This survey was conducted to the enterprises in the manufacturing sector and they analyzed the answers and presented them to the literature. 
According to the results, the major contribution of this research effort was the inclusion of various institutional aspects resulting in a more comprehensive model. Initial experience in the field suggests that manufacturing companies can use the results of their self-assessments as a solid reference point for further strategic measures. Last but not least, Witkowski (2017) introduced the benefits of the Internet of things in the field of logistics and supply chain management into the literature through big data and analytics, one of Industry 4.0's subheadings. According to the results of the study, most of the firms, including logistics companies, are determined to implement technical, technological, and organizational innovation to the product in today's world. Firms are focused on creating value for the customer, which is becoming more conscious and demanding in terms of increased customer requirements related to delivery time delivery services, product availability and reliability. The latest solutions, such as the Internet of Things, Big Data, and Industry 4.0, create opportunities to meet customers' needs and contribute to the development of logistics and supply chain management.

\section{Data Set and Method}

In this study, comparative efficiency of industry 4.0 performances of 25 countries, whose data are available among 36 OECD countries in World Bank, were calculated for the period 2013-2015. To calculate the efficiency of industry 4.0 performances of 25 OECD countries, three input and two output variables were used.

While determining the size of the data set and the number of inputs and outputs to be used, there are different opinions regarding the number of decision-making units (DMU) that make up the sample in order to ensure that DEA provides more consistent results. To accurately measure the effectiveness of the selected decisionmaking units, the number of units required must be at least three times the total of input and output (Vassiloglu and Giokas, 1990: 592).

The inputs used in this study are the high technology product export rate in exports, the rate of information and technology goods export in the exports of the goods, and the number of researchers (per 1 million) in research and development. The outputs used are the number of patent applications (the sum of those resident and non-residents in the country) and the ratio of research and development expenditures in GDP. All variables used in the study were obtained from the World Bank's database (World Bank, 2019).

Data Envelopment Analysis (DEA), Bootstrap Data Envelopment Analysis and Malmquist Total Factor Efficiency (TFV) index was used as to analyze the data and reach the aim of the study. Data envelopment analysis method was preferred to perform a comparative analysis of the effectiveness levels of countries. In the study, if the scales of the decision-making units that make up the sample differ from each other, technical efficacy scores were calculated under the output-oriented condition, which varies according to the scale (VRS) assumption that reflects more effective results. In addition, the bootstrap technical efficiency scores, which show the corrected or deviated values of the efficiency scores, are also included. Total factor efficiency (TFV) scores were used to see the change in effectiveness and efficiency levels over time.

Banker, Charnes and Cooper (1984) developed the model that Charnes, Cooper and Rhodes (1978) put forward under constant return according to the scale and proposed the BCC model under the assumption of variable return according to the scale. The choice of model to be used in DEA depends on whether the inputs and outputs can be controlled. Input model to determine the most appropriate input quality to be used in order to produce a particular output in the most efficient way, the model for the output should be preferred to determine how much output can be obtained with a certain input. However, both models can be used if the decision maker is only concerned with the efficiency status of the DMUs and does not care about the type of activity. In the study, a model was established to maximize the output. The DEA model, determined as the output-based scale (VRS), is given below (Gülel, 2013: 67):

$$
Q_{k}=\min \sum_{i=1}^{m} v_{i} x_{i k}
$$

The constraints of the model;

$$
\sum_{r=1}^{t}\left(u_{r} y_{r k}\right)=1
$$




$$
\sum_{r=1}^{t}\left(u_{r} y_{r j}\right)-\sum_{i=1}^{m}\left(v_{i} x_{i j}\right) \leq 0
$$

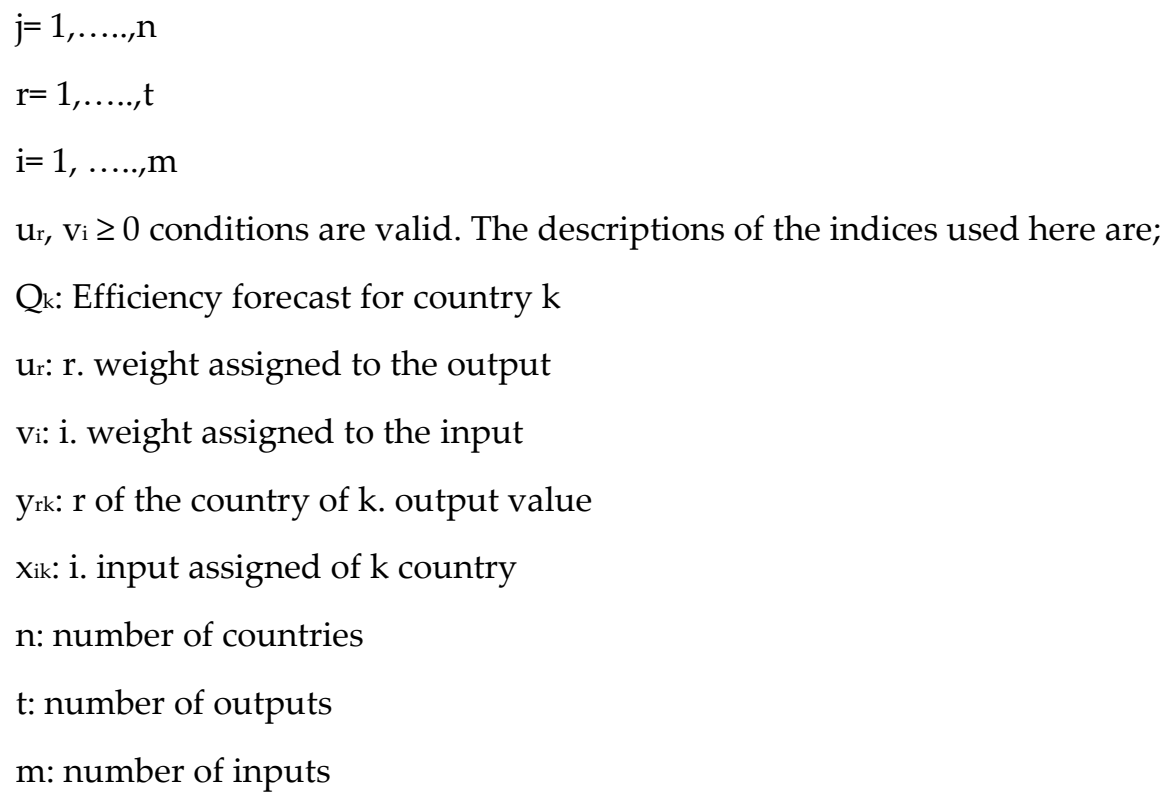

In addition to the technical efficiency scores calculated with the assumption that varies according to the scale (VRS), bootstrap analysis, which gives a corrected, non-deviating prediction of the activity scores, is obtained neutralized estimates. Qk: effectiveness of country $\mathrm{k}, \mathrm{Bi}^{*}$; a set of values drawn from the Qk set and $\varepsilon_{i}^{*}$; These steps are given below to be taken regardless of the K (.) Kernel function (Gülel, 2013: 68):

a) $\mathrm{Qk}, \mathrm{k}=1, \ldots ., \mathrm{n}$ for each $\mathrm{DMU}$

b) Using $Q_{i}=\left\{\begin{array}{c}\beta_{i}^{*}+h \epsilon_{i}^{*}, \beta_{i}^{*}+h \epsilon_{i}^{*} \leq 1 \\ 2-\beta_{i}^{*}-h \epsilon_{i}^{*}\end{array}\right.$, , a sample of $\mathrm{n}$ width is derived from $\mathrm{Qi}(\mathrm{i}=1, \ldots ., \mathrm{N})$ to be Q1b *,...., Qnb*

c) $\mathrm{Xb}^{*}$ pseudo (pseudo) dataset is created: $x^{*}{ }^{*}=\left\{\left(x i b^{*}, y i\right) i=1, \ldots, n\right\}, x_{i b}{ }^{*}=\left(Q_{i} / Q_{i b}{ }^{*}\right) x_{i}, i=1, \ldots, n$

d) $\mathrm{Qk}_{\mathrm{k}, \mathrm{b}^{*}}(\mathrm{k}=1, \ldots, \mathrm{n})$ of $\mathrm{Qk}$ is calculated based on the $\mathrm{xb}^{*}$ dataset

$$
Q_{k, b}^{*}=\min \left\{Q \backslash y_{k} \leq \sum_{i=1}^{n} u_{i} y_{i}, Q x_{k} \geq \sum_{i=1}^{n} u_{i} x_{k, b}^{*} ; Q>0 ; \sum_{i}^{n} u_{i}=1 ; u_{i} \geq 0\right\}
$$

e) Steps 2-4 are repeated $B$ times until $\{Q k, b *, b=1, \ldots ., B\}, k=1, \ldots . ., n$ is achieved.

Effectiveness analysis with data envelopment analysis does not include the effect of time dimension. In other words, analysis is based on a certain period. However, another important issue in efficiency evaluations is the changes occurring in the efficiency level over time. This important change is analyzed by the Malmquist Total Factor Efficiency (TFV) index.

In order to measure total factor efficiency with Malmquist efficiency index, there must be at least two periods. The conclusion drawn from the difference functions for both periods describes the deviations from the maximum average output. This index calculates the relative distance ratios of each data point according to common technology and measures the change in TFV (the technical progress and technological change that creates it) between the two data points and is expressed in the following notation:

$$
\mathrm{m}_{0}\left(\mathrm{y}^{\mathrm{t}}, \mathrm{x}^{\mathrm{t}}, \mathrm{y}^{\mathrm{t}+1}, \mathrm{x}^{\mathrm{t}+1}\right)=\left[\left(\frac{\mathrm{d}_{0}^{\mathrm{t}}\left(\mathrm{y}^{\mathrm{t}+1}, \mathrm{x}^{\mathrm{t}+1}\right)}{\mathrm{d}_{0}^{\mathrm{t}}\left(\mathrm{y}^{\mathrm{t}}, \mathrm{x}^{\mathrm{t}}\right)}\right) \times\left(\frac{\mathrm{d}_{0}^{\mathrm{t}+1}\left(\mathrm{y}^{\mathrm{t}+1}, \mathrm{x}^{\mathrm{t}+1}\right)}{\mathrm{d}_{0}^{\mathrm{t}}\left(\mathrm{y}^{\mathrm{t}}, \mathrm{x}^{\mathrm{t}}\right)}\right)\right]^{\frac{1}{2}}
$$

In this equation, the notation $d_{0}^{t}\left(y^{t+1}, x^{t+1}\right)$ represents the distance from the observations ( $\left.\mathrm{t}+1\right)$ to the technology of the period (t). This equation can be illustrated by the following pattern: 


$$
\mathrm{m}_{0}\left(\mathrm{y}^{\mathrm{t}}, \mathrm{x}^{\mathrm{t}}, \mathrm{y}^{\mathrm{t}+1}, \mathrm{x}^{\mathrm{t}+1}\right) \frac{\mathrm{d}_{0}^{\mathrm{t}+1}\left(\mathrm{y}^{\mathrm{t}+1}, \mathrm{x}^{\mathrm{t}+1}\right)}{\mathrm{d}_{0}^{\mathrm{t}}\left(\mathrm{y}^{\mathrm{t}}, \mathrm{x}^{\mathrm{t}}\right)}\left[\left(\frac{\mathrm{d}_{0}^{\mathrm{t}}\left(\mathrm{y}^{\mathrm{t}+1}, \mathrm{x}^{\mathrm{t}+1}\right)}{\mathrm{d}_{0}^{\mathrm{t}+1}\left(\mathrm{y}^{\mathrm{t}+1}, \mathrm{x}^{\mathrm{t}+1}\right)}\right) \times\left(\frac{\mathrm{d}_{0}^{\mathrm{t}}\left(\mathrm{y}^{\mathrm{t}}, \mathrm{x}^{\mathrm{t}}\right)}{\mathrm{d}_{0}^{\mathrm{t}+1}\left(\mathrm{y}^{\mathrm{t}}, \mathrm{x}^{\mathrm{t}}\right)}\right)\right]^{\frac{1}{2}}
$$

In the equation, out of brackets, it measures the change in output-axis technical activity between $(t)$ and $(t+1)$. The fact that the " $\mathrm{m} 0$ " value included in this value is greater than 1 means that the total factor efficiency increased to the period $(t+1)$ in the period $(t)$; being less than 1 indicates that total factor efficiency decreased from $(t)$ period $(t+1)$ period (Kara et al., 2013: 110).

\section{Findings}

This section includes the VRS (variable scale-based return) technical effectiveness results, bootstrap data envelopment analysis and Malmquist total factor efficiency results of OECD countries for 2013, 2014 and 2015.

Table 1: Technical Effectiveness Scores of Industry 4.0 Performances of OECD Countries

\begin{tabular}{|c|c|c|c|c|c|c|c|c|}
\hline \multirow{2}{*}{ DMU } & \multicolumn{2}{|l|}{2013} & \multicolumn{2}{|l|}{2014} & \multicolumn{2}{|l|}{2015} & \multicolumn{2}{|l|}{ MEAN } \\
\hline & VRS & BOOTSTR & VRS & BOOTSTR & VRS & BOOTSTR & VRS & BOOTSRT \\
\hline Austria & 1 & 0.758416 & 1 & 0.735212 & 1 & 0.734797 & 1 & 0.742808 \\
\hline Belgium & 1 & \begin{tabular}{|l}
0.698424 \\
\end{tabular} & 1 & 0.661235 & 1 & \begin{tabular}{|l|}
0.705646 \\
\end{tabular} & 1 & 0.688435 \\
\hline Canada & 0.765 & 0.562196 & 0.844 & 0.609313 & 0.831 & 0.623513 & 0.813333 & 0.59834 \\
\hline Czech Rep. & 0.881 & 0.744362 & 0.862 & 0.724593 & 0.832 & 0.711802 & 0.858333 & 0.726919 \\
\hline Denmark & 0.894 & 0.673243 & 0.9 & 0.684835 & 1 & 0.783933 & 0.931333 & 0.714003 \\
\hline Estonia & 0.774 & 0.657316 & 0.657 & 0.556529 & 0.719 & \begin{tabular}{|l|}
0.618795 \\
\end{tabular} & 0.716667 & 0.61088 \\
\hline Finland & 1 & 0.621043 & 1 & 0.620764 & 1 & \begin{tabular}{|l|}
0.661658 \\
\end{tabular} & 1 & 0.634488 \\
\hline France & 0.842 & 0.684629 & 0.846 & 0.683899 & 0.854 & \begin{tabular}{|l|}
0.703979 \\
\end{tabular} & 0.847333 & 0.690836 \\
\hline Germany & 1 & 0.766367 & 1 & 0.751369 & 1 & 0.787364 & 1 & 0.768366 \\
\hline Greece & 0.576 & 0.42773 & 0.488 & 0.389185 & 0.495 & 0.398592 & 0.519667 & 0.405169 \\
\hline Japan & 1 & 0.691089 & 1 & 0.663228 & 1 & 0.701646 & 1 & 0.685321 \\
\hline South Korea & 1 & 0.657118 & 1 & 0.639994 & 1 & \begin{tabular}{|l|}
0.665129 \\
\end{tabular} & 1 & 0.65408 \\
\hline Latvia & 0.504 & 0.409176 & 0.53 & 0.42532 & 0.507 & 0.408012 & 0.513667 & 0.414169 \\
\hline Lithuania & 0.53 & 0.420254 & 0.517 & 0.40915 & 0.571 & 0.470103 & 0.539333 & 0.433169 \\
\hline Luxembourg & 0.575 & \begin{tabular}{|l|l|}
0.424099 \\
\end{tabular} & 0.662 & 0.482675 & 0.616 & 0.466148 & 0.617667 & 0.457641 \\
\hline Netherlands & 0.652 & 0.538458 & 0.671 & 0.553267 & 0.672 & 0.563259 & 0.665 & 0.551662 \\
\hline Norway & 1 & 0.585834 & 1 & 0.588447 & 1 & 0.632428 & 1 & 0.602236 \\
\hline Poland & 0.686 & 0.548005 & 0.659 & 0.529952 & 0.689 & \begin{tabular}{|l|}
0.570121 \\
\end{tabular} & 0.678 & 0.549359 \\
\hline Portugal & 0.788 & 0.585917 & 0.802 & 0.607125 & 0.807 & 0.630489 & 0.799 & 0.607844 \\
\hline Slovak Rep. & 0.453 & 0.372996 & 0.476 & 0.389147 & 0.675 & 0.562363 & 0.534667 & 0.441502 \\
\hline Spain & 1 & 0.589698 & 1 & 0.579234 & 1 & 0.628385 & 1 & 0.599106 \\
\hline Sweden & 0.957 & 0.749675 & 0.915 & 0.720021 & 1 & 0.808818 & 0.957333 & 0.759505 \\
\hline Turkey & 1 & 0.595086 & 1 & 0.582722 & 1 & 0.619344 & 1 & 0.599051 \\
\hline U. Kingdom & 0.626 & 0.50314 & 0.604 & 0.478925 & 0.622 & 0.509156 & 0.617333 & 0.497074 \\
\hline USA & 1 & 0.593904 & 1 & 0.579323 & 1 & 0.631372 & 1 & 0.601533 \\
\hline
\end{tabular}

When Table 1 is examined, variable scale-based return (VRS) values and bootstrap efficiency scores of the 25 OECD countries, whose data are available for 2013, 2014 and 2015 are presented. According to 2013, when VRS values are examined, it is observed that the efficiency scores of Austria, Belgium, Finland, Germany, Japan, S. Korea, Norway, Spain, Turkey, and USA are "1", i.e. active countries. In contrast, when the Bootstrap (corrected, deviation-free) activity scores are examined, they show that the most effective decision-making units (countries) are Austria, Belgium, Czech Rep., Denmark, Estonia, France, Germany, Japan, S. Korea, and Sweden. According to results of 2014, VRS values of Austria, Belgium, Finland, Germany, Japan, G. Korea, Norway, Spain, Turkey, and the United States appear to be active countries. Also, Bootstrap (corrected, 


\section{Yıldırım - M. S. Yıldız - İ. Durak 12/3 (2020) 2788-2798}

deviation-free) efficiency scores of 2014 show that the most effective decision-making units are those of countries such as Austria, Belgium, Czech, Denmark, France, Germany, Japan, S. Korea, and Sweden. When the bootstrap efficiency results of 2014 are compared with the previous year (2013), it can be deducted that while Estonia was included in the group of efficient countries in 2013, it lost its efficiency in 2014. According to 2015, when VRS values are examined, the efficiency scores of Austria, Belgium, Denmark, Finland, Germany, Japan, S. Korea, Norway, Spain, Sweden, Turkey, and USA are "1" i.e. efficient countries. In the 2015 VRS results, it can be observed that countries such as Denmark and Sweden are included in the active countries group compared to the other two years (2013 and 2014). When the Bootstrap efficiency scores are examined, the most effective decision-making units are Austria, Belgium, Czech, Denmark, Finland, France, Germany, Japan, Korea, and Sweden. Unlike the previous two years (2013 and 2014), Finland's the bootstrap activity scores of 2015 are in efficient countries group.

Overall, in terms of the average VRS values of OECD countries over the years, Austria, Belgium, Finland, Germany, Japan, S. Korea, Norway, Spain, Turkey and the United States are effective countries, whereas according to bootstrap activity scores, Austria, Belgium, Czech, Denmark, France, Germany, Japan, S. Korea and Sweden are those in the effective countries group. For years, countries such as Norway, Spain, Turkey and the USA which are seen as effective in VRS scores are not among the active decision-making units in bootstrap technical effective scores. In contrast, countries that do not have active value in the VRS scores, such as Denmark, Sweden, Czech Republic, and France, are included in the effective group in the bootstrap technical efficiency scores. As can be seen in the table above, DEA results reveal that countries' effectiveness scores may change over time. A decision-making unit (country) that was active in the previous period could not provide effective in the next period, or a country that was ineffective in the previous period could be included in the group of effective countries in the next period. Therefore, the change in the efficiency of decision-making units over time is calculated with the Malmquist Total Factor Efficiency Index. Malmquist Total Factor Efficiency scores are shown in Table 2 below.

Table 2: Total Factor Efficiency of Industry 4.0 Performance of OECD Countries-Malmquist Scores

\begin{tabular}{|l|l|l|l|}
\hline DMU & $\mathbf{2 0 1 3 - 2 0 1 4}$ & $\mathbf{2 0 1 4 - 2 0 1 5}$ & Mean \\
\hline Austria & 1.008 & 0.988 & 0.998 \\
\hline Belgium & 0.975 & 0.938 & 0.9565 \\
\hline Canada & 1.078 & 0.919 & 0.9985 \\
\hline Czech Rep. & 0.986 & 0.928 & 0.957 \\
\hline Denmark & 0.94 & 1.014 & 0.977 \\
\hline Estonia & 0.857 & 1.059 & 0.958 \\
\hline Finland & 0.898 & 0.941 & 0.9195 \\
\hline France & 1.011 & 0.97 & 0.9905 \\
\hline Germany & 1.012 & 0.951 & 0.9815 \\
\hline Greece & 0.88 & 0.971 & 0.9255 \\
\hline Japan & 1.02 & 0.961 & 0.9905 \\
\hline S. Korea & 0.967 & 0.958 & 0.9625 \\
\hline Latvia & 1.081 & 0.936 & 1.0085 \\
\hline Lithuania & 0.977 & 1.001 & 0.989 \\
\hline Luxembourg & 1.052 & 0.864 & 0.958 \\
\hline Netherlands & 1.035 & 0.966 & 1.0005 \\
\hline Norway & 0.959 & 0.958 & 0.9585 \\
\hline Poland & 0.982 & 1.012 & 0.997 \\
\hline Portugal & 0.955 & 0.918 & 0.9365 \\
\hline Slovak Rep. & 1.074 & 1.374 & 1.224 \\
\hline Spain & 0.961 & 0.939 & 0.95 \\
\hline Sweden & 0.925 & 1.04 & 0.9825 \\
\hline & & & \\
\hline
\end{tabular}


M. Yıldırım - M. S. Yıldız - İ. Durak 12/3 (2020) 2788-2798

\begin{tabular}{|l|l|l|l|} 
Turkey & 1.041 & 0.967 & 1.004 \\
\hline United Kingdom & 0.968 & 0.991 & 0.9795 \\
\hline USA & 0.99 & 0.983 & 0.9865 \\
\hline Mean & $\mathbf{0 . 9 8 5}$ & $\mathbf{0 . 9 8 2}$ & $\mathbf{0 . 9 8 3}$ \\
\hline
\end{tabular}

When Table 2 is examined, the results of Malmquist total factor productivity, which show the change of the effectiveness of OECD countries over time, are shown for 2013-2014 and 2014-2015. For at the 2013-2014 period, the change in the total factor productivity index is 0.985 . Since this value is not greater than 1 , it does not indicate progress. In other words, with respect to the total factor productivity index, a decrease of $1.5 \%$ is observed in the 2013-2014 period $(1-0.985=0.015)$. However, in 2013-2014 period, especially in countries such as Canada (1.078), Latvia (1.081) and Slovakia (1.074), there are serious increasing in Malmquist total factor productivity. However, the increases observed in these countries are not enough for the whole of 2013-2014 period. For the 2014-2015 period, the change in the total factor productivity index is 0.982 . Since this value is not greater than 1, it can be concluded that there is no progress for industry 4.0. For the 2014-2015 period (1$0.982=0.018) \% 1,8$ indicates a state of decline. However, for the period 2014-2015, significant increases in Malmquist total factor efficiencies are observed, especially in countries such as Slovakia (1.374), Estonia (1.059) and Sweden (1.04). However, the increases in the total factor productivity of these countries have not made progress for the overall period of 2014-2015.

\section{Conclusion and Implication}

This study analyzed the comparative effectiveness of Industry 4.0 performances of 25 OECD countries. In the analysis, data envelopment analysis was used with VRS with variable scale based and Bootstrap technical effective results measuring corrected and deviation-free effectiveness, and the Malmquist Total Factor Efficiency index was used to determine the change of activity over time. The analysis results show that in terms of the bootstrap data envelopment analysis, it was obtained that Austria, Belgium, Czech Republic, Denmark, France, Germany, Japan, S. Korea and Sweden were usually effective. Bootstrap Data Envelopment Analysis allows access to resilient estimates of activity scores, but more secure activity results can be accessed. In this case, the necessity of efficiency scores to be deviated-free in order to provide stronger policy arguments increases the popularity of bootstrap data envelopment analysis. VZA results show that countries' effectiveness scores might vary over time. A decision-making unit (country) that was effective in the previous period could not provide effective in the next period, or a country that was ineffective in the previous period could be included in the group of active countries in the next period. Therefore, the change in the efficiency of decision-making units over time is calculated with the Malmquist Total Factor Efficiency Index. When viewed for the period 2013-2014, the change in the total factor productivity index was 0.985 . This value is not greater than 1 , so it did not indicate progress. However, when decision-making units were examined separately for the 2013-2014 period, significant increases in Malmquist total factor efficiencies were observed in countries such as Canada (1.078), Latvia (1.081) and Slovakia (1.074). However, the increases in these countries were not sufficient to make progress for the overall period of 2013-2014. When viewed for the period 2014-2015, the change in the total factor productivity index was 0.982 . Since this value is not greater than 1 , we found out that there was no progress for Industry 4.0. For the period 2014-2015, significant increases in Malmquist total factor efficiencies were observed, particularly in countries such as Slovakia (1.374), Estonia (1.059) and Sweden (1.04). However, the increases in the total factor productivity of these countries did not make any progress for the overall period of 2014-2015.

The results of the current study indicated similar results in the literature, For example, Ünlü and Atik (2018) performed the transition performance of Turkish and EU countries ' enterprises to Industry 4.0 using factor analysis and clustering analysis methods, and as a result of the study, Germany ranked first, while Turkey ranked 15th. These results are parallel to the current result. Meanwhile, Bulut and Akçacı (2017), whose results were similar to this study, was evaluated Industry 4.0 performance of selected countries and it was pointed out that increasing Turkey's R \& D spending had a enhancing effect on technology exports. Öztürk and Alaşahan (2019) evaluated the performance of selected countries in Industry 4.0 by Panel data analysis method and concluded that Turkey should focus on education and R \& D studies and produce more high-tech products in order to become a successful country in Industry 4.0. The concluded results resemble the results of current study. 


\section{Yıldırım - M. S. Yıldız - İ. Durak 12/3 (2020) 2788-2798}

Based on the results of the analysis and the theoretical literature, the authors have some suggestions for future researchers about Industry 4.0. First is that future studies might choose more homogeneous sample while Industry 4.0 performances of decision-making units are measured by data envelopment analysis. Secondly, more attention should be paid to the relationship between Industry 4.0 and education, and education-related indicators could also be included in the analysis. Thirdly, different and more modern methods might be used to measure Industry 4.0. As one of these methods, with the new generation panel data analysis developed in recent years, the horizontal cross-section dependence between the units forming the panel (the case that one of the units that make up the sample group may experience a high probability of affecting other units) could be used for measuring efficiency of countries industry 4.0 situation.

\section{References}

Armentia, J., C.-Mansilla, D. and Ipiña, D. L., (2012). Fighting Against Vampire Appliances Through Ecoaware Things. Sixth International Conference on Innovative Mobile and Internet Services. Ubiquitous Computing. https://doi.org/10.1109/imis.2012.112

Ataman, A. C. (2018). Savunma Sanayinde Endüstri 4.0 Olgunluk Parametrelerinin Tereddütlü Bulanık AHP Yöntemi ile Önceliklendirilmesi, Yayımlanmamış Yüksek Lisans Tezi, Bahçeşehir Üniversitesi, İstanbul.

Banger, G. (2017). Endüstri 4.0 Extra, Dorlion Yayınları, 1.Bask1, Ankara.

Banker, R. D., Charnes, A., and Cooper, W. W. (1984). Some models for estimating technical and scale inefficiencies in data envelopment analysis. Management science, 30(9), 1078-1092.

Brettel, M., Friederichsen, N., Keller, M., and Rosenberg, M. (2014). How Virtualization, Decentralization and Network Building Change the Manufacturing Landscape: An Industry 4.0, Perspective. International journal of mechanical, industrial science and engineering, 8(1), 37-44.

Bulut, E., and Akçacı., T. (2017). Endüstri 4.0 ve İnovasyon Göstergeleri Kapsamında Türkiye Analizi, ASSAM Uluslararası Hakemli Dergi, 7(1), 50-72.

Charnes, A., W. W. Cooper, and E. Rhodes. (1978). "Measuring the Efficiency of Decision-Making Units." European Journal of Operational Research 2 (6): 429-444.

Gilchrist, A. (2016). Industry 4.0: The Industrial Internet of Things, A press.

Görçün, Ö. F. (2016). Dördüncü Endüstri Devrimi, Beta Yayımcılık, İstanbul.

Gülel, F. E. (2013). Avrupa Birliği Ülkeleri Arasında İnternet Kullanım Etkinliği: Simar ve Wilson Yaklaşımı, Dogus University Journal, 14(1), 65-72. https://doi.org/10.31671/dogus.2018.96

Hermann, M., Pentek, T., and Otto, B. (2015). Design Principles for Industrie 4.0 Scenarios: A Aiterature Review. Technische Universität Dortmund, Dortmund.

Howson, C. (2014). Successful Business Intelligence: Unlock the Value of BI and Big Data, Second Edition. USA: McGraw-Hill Education, 3-5.

https://databank.worldbank.org/source/world-development-indicators. (accessed 19.12.2019).

Kara, O., Kayacan, B., and Eratilla, M. (2013). Düzce İli Devlet Orman İşletme Müdürlüklerinin Parametrik Olmayan Yöntemlerle Etkinliğinin Analizi, International Journal of Economic \& Social Research, 9(1), 97123.

Kaufmann, T. (2015). Geschäftsmodelle in Industrie 4.0 und dem Internet der Dinge: der Weg vom Anspruch in die Wirklichkeit, Springer-Verlag. https://doi.org/10.1007/978-3-658-10272-2

Kocsi, B., and Oláh, J. (2017). Potential Connections of Unique Manufacturing and Industry 4.0, LogForum, 13(4).

Lee, I., and Lee, K. (2015). The Internet of Things (IoT): Applications, investments, and challenges for enterprises, Business Horizons, 58(4), 431-440. https://doi.org/10.1016/j.bushor.2015.03.008 
M. Yıldırım - M. S. Yıldız - İ. Durak 12/3 (2020) 2788-2798

Lee, J. (2015). Smart Factory Systems, Informatik Spektrum, 38(3), 1-9.

Lorica, B., and Loukides, M. K. (2016). What Is Artificial Intelligence?, O'Reilly Media, Incorporated.

Manners-Bell, J., and Lyon, K. (2012). The Implications of 3D Printing for the Global Logistics Industry, Transport Intelligence, 1-5.

Nissenbaum, H. (2005). Where Computer Security Meets National Security, Ethics and Information Technology, 7(2), 61-73. https://doi.org/10.1007/s10676-005-4582-3

Obitko, M. and Jirkovský, V. (2015, September). Big Data Semantics in Industry 4.0. In International conference on industrial applications of holonic and multi-agent systems (pp. 217-229), Springer, Cham. https://doi.org/10.1007/978-3-319-22867-9 19.

Ohlhorst, F. J. (2012). Big Data Analytics: Turning Big Data Into Big Money (Vol. 65), John Wiley ve Sons. https://doi.org/10.1002/9781119205005

Öztürk, S., and Alaşahan, Y. (2019). Türkiye'de Endüstri 4.0 Uygulamalarının Değerlendirilmesi: Panel Veri Analizi, Dumlupinar University Journal of Social Science/Dumlupinar Üniversitesi Sosyal Bilimler Dergisi, 61,1-18. https://doi.org/10.29029/busbed.559856

Radziwon, A., Bilberg, A., Bogers, M., and Madsen, E. S. (2014). The Smart Factory: Exploring Adaptive and Flexible Manufacturing Solutions, Procedia engineering, 69, 1184-1190. https://doi.org/10.1016/j.proeng.2014.03.108.

Schumacher, A., Erol, S. and Sihn, W. (2016). A Maturity Model for Assessing Industry 4.0 Readiness and Maturity of Manufacturing Enterprises, Procedia Journal of Manufacturing Science and Technology, 52, 161-166. https://doi.org/10.1016/j.procir.2016.07.040.

Schwab, K. (2016). Dördüncü Sanayi Devrimi, Optimist Yayın Grubu.

Skilton, M., and Hovsepian, F. (2017). The 4th Industrial Revolution: Responding to the Impact of Artificial Intelligence on Business, Springer.

Stock T. and Seliger G. (2016). Opportunities of Sustainable Manufacturing in Industry 4.0, Procedia CIRP, 40(536-541). https://doi.org/10.1016/j.procir.2016.01.129

Thames, L. and Schaefer, D. (2017). Cyber Security for Industry 4.0, New York, Springer.

Thibaud, M., Chi, H., Zhou, W., and Piramuthu, S. (2018). Internet of Things (IoT) in High-Risk Environment, Health and Safety (EHS) Industries: A Comprehensive Review, Decision Support Systems, 108, 79-95. https://doi.org/10.1016/j.dss.2018.02.005

Ünlü, F., and Atik, H. (2018). Türkiye'deki İşletmelerin Endüstri 4.0'a Geçiş Performansı: Avrupa Birliği Ülkeleri ile Karşılaştırmalı Ampirik Analiz, Ankara Avrupa Çalışmaları Dergisi, 17(2), 431-463. https://doi.org/10.32450/aacd.512006

Vassiloglu, M., and Giokas, D. (1990). A study of the relative efficiency of bank branches: an application of data envelopment analysis, Journal of the Operational Research Society, 41(7), 591-597. https://doi.org/10.2307/2583436

Von Solms, R., and Van Niekerk, J. (2013). From Information Security to Cyber Security, Computers and Security, 38, 97-102. https://doi.org/10.1016/j.cose.2013.04.004

Wang, X. and Liu, N. (2014). The Application of Internet of Things in Agricultural Means of Production Supply Chain Management, Advance Material Research, 6, 2304-2310.

Witkowski, K. (2017). Internet of Things, Big Data, Industry 4.0 - Innovative Solutions in Logistics and Supply Chains Management, Procedia Engineering, 182, 763 - 769. https://doi.org/10.1016/j.proeng.2017.03.197

Zheng, P., Wang, H., Sang, Z., Zhong, R.Y., Liu, Y., Liu, C., Mubarok, K., Yu, S. and Xu, X. (2018). Smart Manufacturing Systems for Industry 4.0: Conceptual Framework, Scenarios and Future Perspectives, Frontiers of Mechanical Engineering, 13: 137-150. https://doi.org/10.1007/s11465-018-0499-5. 